\title{
Marinobacter lipolyticus sp. nov., a novel moderate halophile with lipolytic activity
}

\author{
S. Martín, M. C. Márquez, C. Sánchez-Porro, E. Mellado, D. R. Arahal \\ and $\mathrm{A}$. Ventosa
}

Correspondence

A. Ventosa

ventosa@us.es
Department of Microbiology and Parasitology, Faculty of Pharmacy, University of Sevilla, 41012 Sevilla, Spain

\begin{abstract}
In the course of a screening programme in hypersaline habitats of southern Spain to isolate halophilic bacteria that are able to produce different extracellular enzymes, a novel, moderately halophilic bacterium (strain $\mathrm{SM} 19^{\top}$ ) that displays lipolytic activity has been isolated and characterized. Strain $\mathrm{SM} 19^{\top}$ is a Gram-negative rod that grows optimally in culture media that contain $7 \cdot 5 \% \mathrm{NaCl}$. The DNA G $+\mathrm{C}$ content was $57 \cdot 0$ mol\%. According to phenotypic and genotypic data, this strain was assigned to the genus Marinobacter. However, 16S rDNA sequence similarity between strain $\mathrm{SM} 19^{\top}$ and species of the genus Marinobacter was $<96 \cdot 7 \%$; this value is sufficiently low to propose its designation as a novel species. In addition, DNA-DNA hybridization with reference strains of close phylogenetic relatives was between 11 and $19 \%$. On the basis of these data, the inclusion of strain $\mathrm{SM} 19^{\top}$ in the genus Marinobacter as a novel species is proposed, with the name Marinobacter lipolyticus sp. nov. The type strain of the novel species is $\operatorname{SM}_{19}{ }^{\top}\left(=\mathrm{DSM} 15157^{\top}=\mathrm{NCIMB} 13907^{\top}=\mathrm{CIP} 107627^{\top}=\mathrm{CCM} 7048^{\top}\right)$.
\end{abstract}

Isolation and characterization of extracellular hydrolytic enzymes that show optimal activity at different salt concentrations constitutes an interesting research field with potential biotechnological applications. Availability of such enzymes would facilitate different industrial processes that require activity at high salt concentrations.

Moderately halophilic bacteria have adapted to live in a wide range of salt concentrations $(3-15 \% \mathrm{NaCl})$ and constitute an interesting group of micro-organisms that could be used as a source of such salt-adapted enzymes (Ventosa et al., 1998). A screening programme to detect hydrolytic activities, such as protease, amylase, cellulase, pullulanase and lipase, has recently been performed in different hypersaline environments of southern Spain (Sánchez-Porro et al., 2003). This study revealed a wide diversity of moderately halophilic bacteria with the potential to hydrolyse a range of structurally non-related polymers. Among the isolates, 207 moderately halophilic bacteria that display lipolytic activity have been detected. Applications of lipolytic enzymes, which comprise mainly esterases and lipases, are widely found in the food, detergents, pharmaceutical and chemical industries (Jaeger et al., 1999; Pandey et al., 1999). A large number of microbial lipolytic enzymes has been identified and characterized to date; however, no lipolytic enzymes have so far been characterized from moderate halophiles. Taxonomic/phylogenetic studies performed on

The GenBank/EMBL/DDBJ accession number for the 16S rDNA sequence of Marinobacter lipolyticus SM19 ${ }^{\top}$ is AY147906. these halophilic, lipolytic enzyme producers accommodate them within different genera, such as Salinivibrio, Halomonas, Chromohalobacter, Salibacillus, Marinococcus and Marinobacter. In this study, the most promising isolate among the lipolytic producers, strain $\mathrm{SM} 19^{\mathrm{T}}$, was assigned to the genus Marinobacter. This genus was proposed by Gauthier et al. (1992), belongs to the $\gamma$-subclass of the class Proteobacteria and, at the time of writing, includes two species with validly published names: Marinobacter hydrocarbonoclasticus (Gauthier et al., 1992) and Marinobacter aquaeolei (Nguyen et al., 1999). Species of this genus are able to degrade hydrocarbons and some crude oil components.

In this work, we present a taxonomic/phylogenetic study of strain SM19 ${ }^{\mathrm{T}}$, a moderately halophilic bacterium that shows lipolytic activity with potential industrial applications, in order to establish its exact taxonomic position. We show that it constitutes a novel species of the genus Marinobacter, for which we propose the name Marinobacter lipolyticus sp. nov.

Strain SM19 ${ }^{\mathrm{T}}$ was isolated from saline soil in Cádiz, Spain. The following reference strains were used for comparative purposes: M. hydrocarbonoclasticus DSM 8798 ${ }^{\mathrm{T}}$, M. hydrocarbonoclasticus DSM 50418 and Marinobacter aquaeolei DSM $11845^{\mathrm{T}}$. M. hydrocarbonoclasticus DSM 50418 was the type strain of the former species Pseudomonas nautica (Baumann et al., 1972), which was transferred to the genus Marinobacter following a polyphasic taxonomic approach (Spröer et al., 1998) and, consequently, it has been included 
in this study. These strains were cultured on a saline medium $(\mathrm{SW}-7 \cdot 5)$ with a total salt concentration of $7 \cdot 5 \%(\mathrm{w} / \mathrm{v})$, supplemented with $0.5 \%(\mathrm{w} / \mathrm{v})$ yeast extract (Ventosa et al., 1982). All cultures were cultivated at $37^{\circ} \mathrm{C}$ in an orbital shaker (New Brunswick Scientific) at 200 r.p.m. When necessary, solid media were prepared by adding $20 \mathrm{~g}$ Bactoagar $1^{-1}$ (Difco).

Standard phenotypic tests were performed to characterize this new isolate, including Gram reaction, cell morphology, motility, growth under anaerobic conditions, catalase and oxidase production, hydrolysis of gelatin, starch and Tween 80 , as well as other tests that are included in the species description. Procedures for all tests have been described previously (Ventosa et al., 1982; Quesada et al., 1984; Garcia et al., 1987). Unless otherwise indicated, tests were performed in media that contained $7 \cdot 5 \%(\mathrm{w} / \mathrm{v})$ salt, at pH $7 \cdot 5$ and incubated at $37^{\circ} \mathrm{C}$ in sealed containers.

Strain $\mathrm{SM} 19^{\mathrm{T}}$ is a Gram-negative, motile rod that grows optimally in media that contain approximately $7 \cdot 5 \%(\mathrm{w} / \mathrm{v})$ salt and does not grow on nutrient agar without $\mathrm{NaCl}$. This isolate can be considered as a moderately halophilic bacterium according to Kushner \& Kamekura (1988). M. hydrocarbonoclasticus is an extremely halotolerant species, whereas M. aquaeolei is a moderately halophilic bacterium with optimal growth at $5 \% \mathrm{NaCl}$. Strain $\mathrm{SM} 19^{\mathrm{T}}$ grows at $15-40{ }^{\circ} \mathrm{C}$ and $\mathrm{pH} 5-10$; optimal growth occurs at $37^{\circ} \mathrm{C}$ and $\mathrm{pH} 7 \cdot 5$. The new isolate is strictly aerobic and catalase- and oxidase-positive.

Ability to utilize 95 different compounds was tested by using the Biolog GN automatic identification system. Strains were grown on isolate medium at $37^{\circ} \mathrm{C}$ for $24 \mathrm{~h}$ and suspended in pre-warmed sterile saline medium (3\% $\mathrm{NaCl}$ ) within the density range specified by the manufacturer (determined with a Biolog model 21101 photometer). Immediately after suspending the cells in saline solution, suspensions were transferred into sterile multichannel pipetter reservoirs and the Biolog GN MicroPlates were inoculated with $125 \mu \mathrm{l}$ cell suspension per well by means of an eight-channel repeating pipetter. Inoculated Biolog GN plates were incubated at $37^{\circ} \mathrm{C}$ for $24 \mathrm{~h}$ and the results were read with a MicroPlate reader, using MicroLog 3.59 computer software to perform automated reading and identification. The results obtained are included below in the description of the species.

In this work, the almost-complete 16S rDNA sequence (approx. $1443 \mathrm{nt}$ ) of strain $\mathrm{SM} 19^{\mathrm{T}}$ was obtained. For this purpose, DNA was extracted and precipitated by following the CTAB (cetyltrimethylammonium bromide) protocol for bacterial genomic DNA preparation (Wilson, 1987) and PCR amplification of the 16S rRNA gene was carried out by using methods that have been described previously in detail (Mellado et al., 1995). 16S rDNA sequence analyses were performed with the ARB software package (Ludwig \& Strunk, 1996) as reported by Arahal et al. (2002). Based on this analysis, the phylogenetic position of strain $\mathrm{SM} 19^{\mathrm{T}}$ was determined to be within the genus Marinobacter (Fig. 1). With respect to the sequences of the type species of the genus, $M$. hydrocarbonoclasticus, similarities were between 96.4\% (with GenBank sequence no. X67022) and 96.7\% (with AB021372, Y16735 and AB019148). X67022 corresponds to strain ATCC $49840^{\mathrm{T}}$, the type strain of the species, whereas AB021372 and AB019148 are equivalent sequences of M. hydrocarbonoclasticus ATCC 27132 (DSM 50418), which was the type strain of Pseudomonas nautica (Spröer et al., 1998). Although information about the strain used to obtain sequence Y16735 is not available, it is almost coincident with AB021372.

Sequence similarities of strain $\mathrm{SM} 19^{\mathrm{T}}$ with respect to $M$. aquaeolei are $96 \cdot 7 \%$ (GenBank no. AJ000726, sequence of the type strain $\mathrm{VT} 8^{\mathrm{T}}$ ) and $97 \cdot 7 \%$ (AF173969, sequence of strain KT02ds19). However, the study in which the latter sequence was reported (Eilers et al., 2000) is an ecological article that is related to the abundance of pelagic bacteria in the North Sea and does not follow polyphasic taxonomic criteria. In our opinion, it would be more appropriate to consider strain KT02sd19 as Marinobacter sp.

Highest similarity values to the sequence of strain $\mathrm{SM} 19^{\mathrm{T}}(98 \cdot 0-98 \cdot 8 \%)$ corresponded to partially determined sequences, which are not significant for taxonomic purposes. 'Marinobacter marinus' has low sequence similarity to

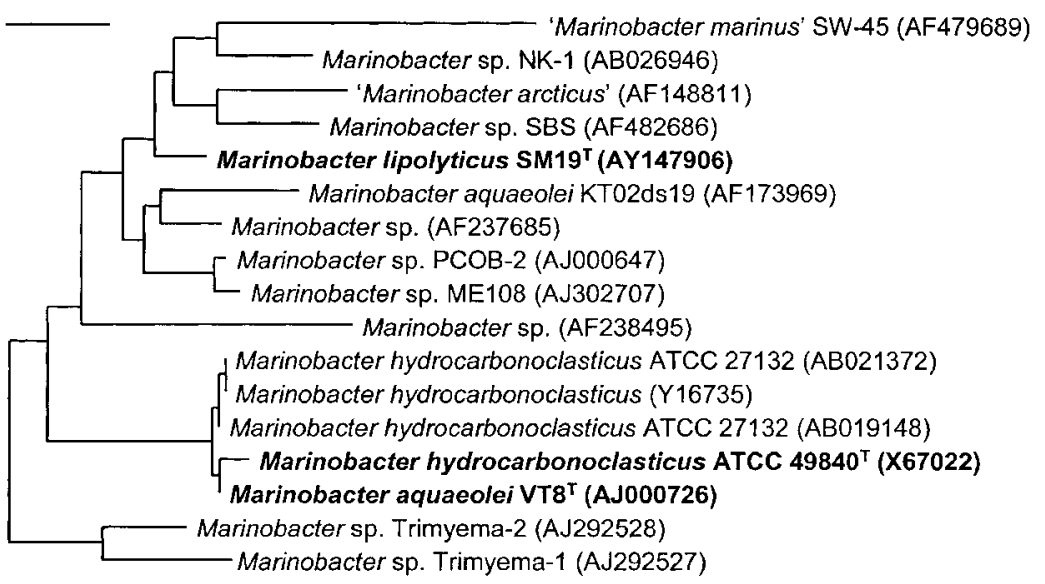

Fig. 1. Phylogenetic tree based on $16 \mathrm{~S}$ rRNA sequences, showing the relationship of Marinobacter lipolyticus $\mathrm{SM} 19^{\top}$ to other members of the genus Marinobacter. Root not shown. Sequences corresponding to the type strains of Marinobacter species are shown in bold. Accession numbers of the sequences used in this study are shown in parentheses after the strain designation. Bar, $1 \%$ sequence divergence. 
strain $\mathrm{SM} 19^{\mathrm{T}}(94 \cdot 8 \%)$ and 'Marinobacter arcticus' shows $98.0 \%$ sequence similarity to strain $\mathrm{SM}^{\mathrm{T}}{ }^{\mathrm{T}}$. However, these names have not yet been validly published. Moreover, the article in which the latter organism is studied (Button \& Robertson, 2001) does not report any taxonomic description of this species. In conclusion, the results of the phylogenetic analyses clearly indicate that strain $\mathrm{SM} 19^{\mathrm{T}}$ belongs to the genus Marinobacter but is sufficiently distant (with similarity values of $<97 \%$ ) to other members of the genus, giving support to its proposal as a novel species.

Cellular fatty acids of strain $\mathrm{SM} 19^{\mathrm{T}}$ and the type strains of M. aquaeolei and M. hydrocarbonoclasticus were analysed with the MIDI Microbial Identification system. Cells were cultured in SW-7.5 medium at $37^{\circ} \mathrm{C}$ for $24 \mathrm{~h}$. Results of the cellular fatty acid analysis are shown in Table 1 . The predominant fatty acids of strain $\mathrm{SM} 19^{\mathrm{T}}$ were $\mathrm{C}_{16: 0}$, $\mathrm{C}_{18: 1} \omega 9 c, \mathrm{C}_{12: 0} 3-\mathrm{OH}$ and $\mathrm{C}_{16: 1} \omega 9 c$. The fatty acid profile is very similar to those of other species of the genus Marinobacter (Spröer et al., 1998; Nguyen et al., 1999).

Table 1. Cellular fatty acid compositions of strain $\mathrm{SM} 19^{\top}$ and related species of the genus Marinobacter

Species: 1, M. lipolyticus SM19 ${ }^{\mathrm{T}}$; 2, M. aquaeolei DSM $11845^{\mathrm{T}}$; 3, M. hydrocarbonoclasticus DSM $8798^{\mathrm{T}}$. Values are percentages of total fatty acids; values $<1 \%$ are not shown.

\begin{tabular}{|lccc|}
\hline Fatty acid & $\mathbf{1}$ & $\mathbf{2}$ & $\mathbf{3}$ \\
\hline $\mathrm{C}_{10: 0}$ & $1 \cdot 5$ & $0 \cdot 9$ & $1 \cdot 0$ \\
$\mathrm{C}_{12: 0}$ & $8 \cdot 3$ & $4 \cdot 7$ & $6 \cdot 5$ \\
$\mathrm{C}_{14: 0}$ & - & $2 \cdot 8$ & $2 \cdot 8$ \\
$\mathrm{C}_{15: 0}$ & $1 \cdot 0$ & $1 \cdot 4$ & $1 \cdot 7$ \\
$\mathrm{C}_{16: 0}$ & $28 \cdot 5$ & $29 \cdot 9$ & $30 \cdot 3$ \\
$\mathrm{C}_{17: 0}$ & $3 \cdot 6$ & $3 \cdot 6$ & $3 \cdot 5$ \\
$\mathrm{C}_{18: 0}$ & $2 \cdot 7$ & $3 \cdot 2$ & $1 \cdot 8$ \\
$10-$ methyl $\mathrm{C}_{16: 0}$ & $4 \cdot 0$ & $1 \cdot 0$ & $1 \cdot 0$ \\
$\mathrm{C}_{16: 1} \omega 9 c$ & $10 \cdot 5$ & $8 \cdot 0$ & $9 \cdot 4$ \\
$\mathrm{C}_{17: 1} \omega 8 c$ & $2 \cdot 9$ & $2 \cdot 8$ & $2 \cdot 8$ \\
$\mathrm{C}_{18: 1} \omega 7 c$ & $2 \cdot 3$ & $1 \cdot 0$ & $0 \cdot 48$ \\
$\mathrm{C}_{18: 1} \omega 9 c$ & $13 \cdot 9$ & $26 \cdot 3$ & $19 \cdot 6$ \\
$\mathrm{C}_{12: 0} 3-\mathrm{OH}$ & $11 \cdot 3$ & $7 \cdot 6$ & $10 \cdot 3$ \\
\hline
\end{tabular}

For determination of the DNA base composition of strain $\mathrm{SM} 19^{\mathrm{T}}$, DNA was extracted and purified by the method of Marmur (1961) and its G+C content was determined according to Marmur \& Doty (1962) by using the equation of Owen \& Hill (1979). The DNA G + C content of strain $\mathrm{SM} 19^{\mathrm{T}}$ was $57 \cdot 0 \mathrm{~mol} \%$. This value is similar to those described for M. hydrocarbonoclasticus $(57.5 \mathrm{~mol} \%$; Spröer et al., 1998) and M. aquaeolei (55.7 mol\%; Nguyen et al., 1999).

DNA-DNA hybridization was studied by the competition procedure of Johnson (1994), described in detail elsewhere (Arahal et al., 2001). Hybridization experiments were carried out under optimal conditions at a temperature of $54.5^{\circ} \mathrm{C}$, which is within the limits of validity for the filter method (De Ley \& Tijtgat, 1970). Hybridization (\%) was calculated as described by Johnson (1994). Hybridization levels between strain $\mathrm{SM}^{\mathrm{T}}{ }^{\mathrm{T}}$ and M. hydrocarbonoclasticus and M. aquaeolei are shown in Table 2. The low hybridization values (11-19\%) obtained in this study clearly demonstrate that isolate $\mathrm{SM} 19^{\mathrm{T}}$ represents a novel species of the genus Marinobacter.

Lipolytic activity of the new isolate was detected by screening for zones of hydrolysis around colonies growing on SW-10 plates that contained $1 \%$ Tween 80 , after incubation for $48 \mathrm{~h}$. Substrate specificity of the enzyme was studied by performing a spectrophotometric assay that used different $p$-nitrophenyl esters (Winkler \& Stuckmann, 1979). Highest activity was observed with $p$-nitrophenyl caprilate $(100 \%)$. Activity was lower towards $p$-nitrophenyl esters with a longer chain, such as $p$-nitrophenyl laureate (42\%), $p$-nitrophenyl palmitate (17\%) and p-nitrophenyl stearate $(8 \%)$. In addition, the production of extracellular lipolytic activity during growth of strain $\mathrm{SM} 19^{\mathrm{T}}$ was determined. Strain $\mathrm{SM} 19^{\mathrm{T}}$ was able to grow in saline media that contained $2-15 \%$ total salt, with optimum growth at $7 \cdot 5 \%$ salt. To determine the influence of salt on lipolytic activity, different saline media were used for bacterial growth. The highest level of activity in the supernant was reached after $8 \mathrm{~h}$ cultivation in medium SW $-7 \cdot 5$ at $37^{\circ} \mathrm{C}$ and $\mathrm{pH} 7 \cdot 2$. Activity was slightly lower in saline medium that contained $5 \% \mathrm{NaCl}$; however, activity decreased severely when SW-10 was used.

Table 2. DNA G $+\mathrm{C}$ contents and levels of DNA-DNA relatedness for Marinobacter lipolyticus and related species of the genus Marinobacter

\begin{tabular}{|lcc|}
\hline Source of unlabelled DNA & $\begin{array}{c}\text { DNA G+C } \\
\text { content (mol\%) }\end{array}$ & $\begin{array}{c}\text { Hybridization with }{ }^{3} \text { H-labelled } \\
\text { DNA from M. lipolyticus SM19 }{ }^{\text {T }} \text { (\%) }\end{array}$ \\
\hline M. lipolyticus SM19 ${ }^{\mathrm{T}}$ & $57 \cdot 0$ & 100 \\
M. hydrocarbonoclasticus DSM $8798^{\mathrm{T}}$ & $57 \cdot 3^{\star}$ & 11 \\
M. hydrocarbonoclasticus DSM 50418 & $57 \cdot 7^{\star}$ & 19 \\
M. aquaeolei DSM $11845^{\mathrm{T}}$ & $55 \cdot 7^{\star}$ & 13 \\
\hline
\end{tabular}

${ }^{\star}$ Data from Spröer et al. (1998) and Nguyen et al. (1999). 
Overall, our results show that strain $\mathrm{SM} 19^{\mathrm{T}}$ represents a novel species of the genus Marinobacter, for which the name Marinobacter lipolyticus sp. nov. is proposed.

\section{Description of Marinobacter lipolyticus sp. nov.}

Marinobacter lipolyticus (li.po.ly'ti.cus. Gr. n. lipos fat; N.L. adj. lyticus from Gr. adj. lytikos dissolving; N.L. adj. lipolyticus fat-dissolving).

Gram-negative, rod-shaped cells that are $0 \cdot 3-0 \cdot 5 \times 2 \cdot 5-$ $3.5 \mu \mathrm{m}$ in size and occur singly, in pairs or in short chains. Motile and non-spore-forming. Colonies on SW-7.5 medium are circular, convex, slightly elevated, $2-3 \mathrm{~mm}$ in diameter and cream-pigmented. Growth occurs in the presence of $1-15 \%(\mathrm{w} / \mathrm{v})$ total salt; optimal growth occurs in the presence of $7 \cdot 5 \%(\mathrm{w} / \mathrm{v})$ total salt. No growth occurs in the absence of salt. Grows occurs at $15-40{ }^{\circ} \mathrm{C}$ (optimal temperature, $37^{\circ} \mathrm{C}$ ) and at $\mathrm{pH} 5 \cdot 0-10 \cdot 0($ optimal $\mathrm{pH}, 7 \cdot 5)$. Strictly aerobic. Catalase and oxidase are produced. Acid is produced from D-glucose, maltose and D-mannitol. Acid is not produced from glycerol, D-lactose or D-melibiose. Tween 80 is hydrolysed, but DNA, gelatin and starch are not. Indole, methyl red, phosphatase, Voges-Proskauer, phenylalanine deaminase, arginine dihydrolase and lysine and ornithine decarboxylase tests are negative. Simmons' citrate test is positive. Nitrate and nitrite are not reduced. The following compounds are utilized as sole carbon and energy sources: dextrin, glycogen, Tween 40 , Tween $80, \mathrm{~N}$-acetyl-Dglucosamine, D-fructose, D-glucose, maltose, D-mannitol, D-trehalose, methyl pyruvate, D-gluconic acid, inosine and thymidine. The following compounds are not utilized as sole carbon and energy sources: $\alpha$-cyclodextrin, $N$-acetyl-Dgalactosamine, adonitol, L-arabinose, D-arabitol, cellobiose, $\mathrm{i}$-erythritol, L-fucose, D-galactose, m-inositol, $\alpha$-D-lactose, lactulose, D-mannose, D-melibiose, methyl $\beta$-D-glucoside, D-psicose, D-raffinose, L-rhamnose, D-sorbitol, sucrose, turanose, xylitol, monomethyl succinate, acetic acid, cisaconitic acid, citric acid, formic acid, D-galactonic acid, Dglucosaminic acid, D-glucuronic acid, $\alpha$-hydroxybutyric acid, $\beta$-hydroxybutyric acid, $\gamma$-hydroxybutyric acid, $p$ hydroxyphenylacetic acid, itaconic acid, $\alpha$-ketobutyric acid, $\alpha$-ketoglutaric acid, $\alpha$-ketovaleric acid, DL-lactic acid, malonic acid, propionic acid, quinic acid, D-saccharic acid, sebacic acid, succinic acid, bromosuccinic acid, succinamic acid, glucuronamide, alaninamide, D-alanine, L-alanine, Lalanylglycine, L-asparagine, L-aspartic acid, L-glutamic acid, glycyl L-aspartic acid, glycyl L-glutamic acid, L-histidine, hydroxy L-proline, L-leucine, L-ornithine, L-phenylalanine, L-proline, L-pyroglutamic acid, D-serine, L-serine, Lthreonine, DL-carnitine, $\gamma$-aminobutyric acid, urocanic acid, uridine, phenylethylamine, putrescine, 2-aminoethanol, 2,3-butanediol, glycerol, DL- $\alpha$-glycerol phosphate, glucose 1-phosphate and glucose 6-phosphate. The $\mathrm{G}+\mathrm{C}$ content of the DNA is $57 \cdot 0 \mathrm{~mol} \%$ ( $T_{\mathrm{m}}$ method).

The type strain is $\mathrm{SM} 19^{\mathrm{T}}\left(=\mathrm{DSM} 15157^{\mathrm{T}}=\right.$ NCIMB $13907^{\mathrm{T}}$ $\left.=\mathrm{CIP} 107627^{\mathrm{T}}=\mathrm{CCM} 7048^{\mathrm{T}}\right)$. Habitat: saline soil.

\section{Acknowledgements}

This study was supported by grants from the Quality of Life and Management of Living Resources Programme of the European Commission (QLK3-CT-2002-01972), Spanish Ministerio de Ciencia y Tecnología (PB98-1150) and Junta de Andalucía. S. M. and C.S.-P. were supported by fellowships from Junta de Andalucía and Spanish Ministerio de Ciencia y Tecnología, respectively.

\section{References}

Arahal, D. R., García, M. T., Ludwig, W., Schleifer, K. H. \& Ventosa, A. (2001). Transfer of Halomonas canadensis and Halomonas israelensis to the genus Chromohalobacter as Chromohalobacter canadensis comb. nov. and Chromohalobacter israelensis comb. nov. Int J Syst Evol Microbiol 51, 1443-1448.

Arahal, D. R., Ludwig, W., Schleifer, K. H. \& Ventosa, A. (2002). Phylogeny of the family Halomonadaceae based on $23 \mathrm{~S}$ and $16 \mathrm{~S}$ rDNA sequence analyses. Int J Syst Evol Microbiol 52, 241-249.

Baumann, L., Baumann, P., Mandel, M. \& Allen, R. D. (1972). Taxonomy of aerobic marine eubacteria. J Bacteriol 110, 402-429.

Button, D. K. \& Robertson, B. R. (2001). Determination of DNA content of aquatic bacteria by flow cytometry. Appl Environ Microbiol 67, 1636-1645.

De Ley, J. \& Tijtgat, R. (1970). Evaluation of membrane filter methods for DNA-DNA hybridization. Antonie van Leeuwenhoek 36, 461-474.

Eilers, H., Pernthaler, J., Glöckner, F. O. \& Amann, R. (2000). Culturability and in situ abundance of pelagic bacteria from the North Sea. Appl Environ Microbiol 66, 3044-3051.

Garcia, M. T., Ventosa, A., Ruiz-Berraquero, F. \& Kocur, M. (1987). Taxonomic study and amended description of Vibrio costicola. Int J Syst Bacteriol 37, 251-256.

Gauthier, M. J., Lafay, B., Christen, R., Fernandez, L., Acquaviva, M., Bonin, P. \& Bertrand, J.-C. (1992). Marinobacter hydrocarbonoclasticus gen. nov., sp. nov., a new, extremely halotolerant, hydrocarbondegrading marine bacterium. Int J Syst Bacteriol 42, 568-576.

Jaeger, K. E., Dijkstra, B. W. \& Reetz, M. T. (1999). Bacterial biocatalysts: molecular biology, three-dimensional structures, and biotechnological applications of lipases. Annu Rev Microbiol 53, 315-351.

Johnson, J. L. (1994). Similarity analysis of DNAs. In Methods for General and Molecular Bacteriology, pp. 655-681. Edited by P. Gerhardt, R. G. E. Murray, W. A. Wood \& N. R. Krieg. Washington, DC: American Society for Microbiology.

Kushner, D. J. \& Kamekura, M. (1988). Physiology of halophilic eubacteria. In Halophilic Bacteria, vol. I, pp. 109-140. Edited by F. Rodríguez-Valera. Boca Raton, FL: CRC Press.

Ludwig, W. \& Strunk, O. (1996). ARB - a software environment for sequence data (http://www.arb-home.de/).

Marmur, J. (1961). A procedure for the isolation of deoxyribonucleic acid from microorganisms. J Mol Biol 3, 208-218.

Marmur, J. \& Doty, P. (1962). Determination of the base composition of deoxyribonucleic acid from its thermal denaturation temperature. J Mol Biol 5, 109-118.

Mellado, E., Moore, E. R. B., Nieto, J. J. \& Ventosa, A. (1995). Phylogenetic inferences and taxonomic consequences of $16 \mathrm{~S}$ ribosomal DNA sequence comparison of Chromohalobacter marismortui, Volcaniella eurihalina, and Deleya salina and reclassification of $V$. eurihalina as Halomonas eurihalina comb. nov. Int $J$ Syst Bacteriol 45, 712-716. 
Nguyen B. H., Denner, E. B. M., Dang, T. C. H., Wanner, G. \& Stan-Lotter, H. (1999). Marinobacter aquaeolei sp. nov., a halophilic bacterium isolated from a Vietnamese oil-producing well. Int J Syst Bacteriol 49, 367-375.

Owen, R. J. \& Hill, L. R. (1979). The estimation of base compositions, base pairing and genome size of bacterial deoxyribonucleic acids. In Identification Methods for Microbiologists, 2nd edn, pp. 217-296. Edited by F. A. Skinner \& D. W. Lovelock. London: Academic Press.

Pandey, A., Benjamin, S., Soccol, C. R., Nigam, P., Krieger, N. \& Soccol, V. T. (1999). The realm of microbial lipases in biotechnology. Biotechnol Appl Biochem 29, 119-131.

Quesada, E., Ventosa, A., Ruiz-Berraquero, F. \& RamosCormenzana, A. (1984). Deleya halophila, a new species of moderately halophilic bacteria. Int J Syst Bacteriol 34, 287-292.

Sánchez-Porro, C., Martín, S., Mellado, E. \& Ventosa, A. (2003). Diversity of moderately halophilic bacteria producing extracellular hydrolytic enzymes. J Appl Microbiol 94, 295-300.
Spröer, C., Lang, E., Hobeck, P., Burghardt, J., Stackebrandt, E. \& Tindall, B. J. (1998). Transfer of Pseudomonas nautica to Marinobacter hydrocarbonoclasticus. Int J Syst Bacteriol 48, 14451448.

Ventosa, A., Quesada, E., Rodriguez-Valera, F., Ruiz-Berraquero, F. \& Ramos-Cormenzana, A. (1982). Numerical taxonomy of moderately halophilic Gram-negative rods. J Gen Microbiol 128, 1959-1968.

Ventosa, A., Nieto, J. J. \& Oren, A. (1998). Biology of moderately halophilic aerobic bacteria. Microbiol Mol Biol Rev 62, 504-544.

Wilson, K. (1987). Preparation of genomic DNA from bacteria. In Current Protocols in Molecular Biology, pp. 2.4.1-2.4.2. Edited by F. M. Ausubel, R. Brent, R. E. Kingston, D. D. Moore, J. G. Seidman, J. A. Smith \& K. Struhl. New York: Wiley.

Winkler, U. K. \& Stuckmann, M. (1979). Glycogen, hyaluronate, and some other polysaccharides greatly enhance the formation of exolipase by Serratia marcescens. J Bacteriol 138, 663-670. 